\title{
On the Eros of Species
}

JS: When I think of "love," I think of Nietzsche and the idea that we cannot live without certain illusions, love being near the top of the heap. Nietzsche delighted in lopping off comfortable illusions and beliefs. Most people cannot imagine even trimming their hair.

RB: First you must tell me what you mean by "love." Orwithout the ironic varnish-love. Certainly the evolutionary imperative is not an illusion. Indeed it may be the only truth.

JS: How do you imagine that this "imperative" is "love" except in the most metaphorical way?

RB: As Mrs. Moore says in A Passage to India, "Love in a cave, love in a church-what's the difference?" Once we brush aside the Arthurian legends and their Hollywood variations, love is essentially the evolutionary imperative to reproduce. Could anything be less "metaphorical"?

JS: Why even call that "love"? It looks like basic instinct to me. Why not just say of "love" what Henry Ford said of "history"? It is bunk. Or perhaps merely a form of lunacy.

RB: Love is neither illusion nor bunk. On the contrary, it is the most powerful and all-encompassing of human emotions. But we find ourselves at a disadvantage, poking and prodding at the flaccid, four-letter word that English provides. Better to turn to the Greeks, who distinguish erōs (passionate love) from agape (general

How to cite this book chapter:

Begam, R. and Soderholm, J. 20I 5. On the Eros of Species. In: Begam, R. and Soderholm, J. Platonic Occasions: Dialogues on Literature, Art and Culture. Pp. 95-I07. Stockholm: Stockholm University Press. DOI: http://dx.doi. org/Io.I 6993/sup.baa.f. License: CC-BY-NC-ND. 
or filial love) from philia (friendship). Plato begins to muddy the definitional waters in Symposium, when he conflates the philosophical love of beauty with the eroticized love of the body.

Confusion deepens in the Middle Ages with the advent of amour courtois, which mixes physical and religious "passions" and produces two of the most benighted figures in all of literary history, Dante and Petrarch. The Florentine poet is a medieval Humbert Humbert, absurdly "falling in love" at the age of nine with a certain Beatrice Portinari, one year his junior. Terrified of the flesh-andblood woman, he spends his youth swooning over her pubescent image until she finally has the good sense to die at the age twentyfour. This happy event inspires him to develop a revolutionary new poetry (stil novo) and later to derive an entire cosmography-not to mention the greatest epic of the period-from the fourteenthcentury equivalent of Lolita's mercurochromed knees.

As for Petrarch, he literally takes sublation to new heightsor, depending on your point of view, depths-when he ascends Mt. Ventoux, transforming an amble up a mountain into a transcendent journey of the soul. His vision of earth-shattering beauty comes to him in the form of Laura de Noves, whom he first sees on Good Friday, I327, and then proceeds to adore from afar, his privates trussed up in lover's knots more elaborate than his own rime sparse. Better to have cold, gilded laurels than hot-blooded Laura. In a delicious turn of fate, the lady marries Hugues de Sade, an ancestor of the future Marquis.

In other words, erōs is no mere metaphor. It is as real and substantial as the sweaty thighs of an English barmaid or a French coquette. Darwin has a thousand times more to tell us about real love than all the poets who ever sang, suffered or simpered.

JS: So, you want to write a book called On the Eros of Species. I am not against the idea. I just don't know what erōs really has to do with evolution, unless you see in natural selection the mechanisms of erotic love, rather than the micro-gestures of genetic variation.

Tell me how you would analyze the following episode taken from my always-contingent "erotic life." A few years ago my mother, trying to do a bit of match-making (maternal selection?) told me about a novelist in England called Emma Darwin, who is indeed the 
great-great-granddaughter of Charles. I did a bit of research and discovered that Emma had recently published a novel entitled The Mathematics of Love. It may be that Darwin's (naturally-selected?) scion has a thousand times more to tell us about love than the poets you so diabolically limned and maligned. But my story is not over. Being my mother's scion and heir to her ideas about opportunism ("Nothing ventured, nothing gained," she programmed into me), I ventured out and bought a copy of Darwin's novel and also wrote Miss Darwin an eager e-mail wherein I suggested we might go out for a coffee, I being a fellow-writer and living in Canterbury.

To my delight, she replied and her words stirred a bit of passionate, perhaps even genetically-opportunistic, longing in me. I began to read her novel. After forty-one pages, I found (sexually selected?) only three sentences I liked. I never wrote to Emma again. End of "romance." I rejected her on grounds of aesthetic incompatibility. Is that related to the way animals reject one another because one's peacock-feathers are not as brilliantly colored as another's? If I had courted and married Charles's great-great-granddaughter, would it have been—genetically—a Darwin/win situation for my own progeny and their proclivities for composing prepossessing prose? Is there, as Emma surmised-but, to my dismay, wrote inadequately about-a mathematics of love? Is this what her famous forebear was also trying to tell us? And, finally, what does it mean when I "peacock" my prose-style to seduce my readers? Is "metaphor" an exaggerated feature of (literary) morphology designed to attract coy or resistant readers? Does this partly explain the history of love poetry (and indeed all literature) and its often florid, figurative language?

RB: I don't have to write On the Eros of Species. It's already been written in the intricate patternings of our DNA that help determine who we are and how we act. What inspires us when we see a beautiful woman ("das Ewige-Weibliche zieht uns hinan") has nothing to do with Plato's conception of Beauty or Dante's vision of Beatrice, and everything to do with what Schopenhauer called Will and Nietzsche called the Dionysian. A less poetic term for this is the "evolutionary imperative," or to speak in more materialist and reductive terms, the reptilian part of the human brain. Of course, contemporary Evolutionary Psychology under- 
stands that human beings are subtle and complex animals, who no longer live in caves or beat each other with clubs (except in certain American cities). In the contemporary West-i.e., in advanced and modernized societies-wrestling with words and symbols is more highly prized and more handsomely rewarded than wrestling with saber-toothed tigers. Even within the context of a fairly primitive culture like Mycenae, Homer understands that Odysseus is an evolutionary winner and Achilles is an evolutionary loser. And the rules are pretty simple. Women like winners and men like women. Ergo, the "man of many figures," the man who is polytropos, is likely to fare better in the natural selection crap-shoot than the man of thumos.

But this is not the entire story. If at bottom it is the evolutionary imperative that drives us, that imperative is not indifferent to the ornaments and refinements of culture. The unfortunate Miss Darwin apparently has a prose style about as attractive as a Galapagos turtle. As Gwendolen says to Jack in The Importance of Being Earnest, certain words "produce vibrations" while others do not. Emma's did not. But please note that if "Emma" had been "Edward," you would not have written in the first place. What attracted your interest was not a good prose style or an illustrious ancestor, but a skirt and all that it promised. When it turned out that the skirt, at least as it appeared in print, was dowdy and dull, you took to your heels. Could anything be more classically male? Emma's great-great grandfather would have smiled knowingly and made a note in his journal.

JS: That I skirted her skirt had less to do with her being female than with her undesirable features as a prime-mate, I assure you. Those features kept me even from pushing my prim pawn to square two, the Coffee Date in London. But has evolution evolved? Are you really content to think our mating rituals are programmed by the prerogatives of DNA? The reptilian brain does not court women, even if it does lust after them. Women do like winners but often end up with losers. How do you account for that? And some men-the erōs that dare not speak its name?-love men, and thus throw a huge "monkey" wrench into the perpetuation of DNA and the telos of the Species. 
RB: R-complex, limbic system, neo-cortex. One is reminded of Plato's tripartite division of the soul in Phaedrus-black horse, white horse, charioteer. But if the neo-cortex is in the driver's seat, what propels the vehicle forward (Freud's "sex-drive") is an ink-colored beast that looks like a cross between Sea-Biscuit and Godzilla. So, yes, it's a combination of nature and culture, of reptilian brain and cerebral hemisphere, but it's the former that gets us off the sofa and on the prowl in the hope that we will land back on the sofa with Zerlina or Donna Anna or Donna Elvira.

Why do some women end up with losers? Because there aren't enough winners to go around. Why do some men end up with men? Because the logic of natural selection is endlessly permuting variety-Lucretius' clinamen-and sometimes the "swerve" swerves away from pure functionality. The evolutionary imperative does not hard-wire us to reproduce but to copulate. The logic of the system is massive dissemination, with the understanding that if enough seeds fall, some will grow.

JS: Surely, Zerlina, rather than the other two. She is no Donna, thank heavens. Zerlina at least learns how not to be a shrill harpy, but how to seduce and be seduced, something she displays in her famous duettino with the Don. I love how she extorts kindness and forgiveness from Masetto by asking him to beat her ("Batti, batti o bel Masetto"), which of course he cannot, will not do, once the balm of her voice gentles him.

What men represent to women remains a mystery to me that biology only partly explains. Are women driven by biological imperatives more than men are?

RB: Perhaps Zerlina provides the answer. In "Batti, batti o bel Masetto," she presents herself as the meek and submissive woman ("staro qui come angellina") who surrenders, lamb-like, before the masculine power of Masetto. But her "submission," as he realizes, is nothing more than a pose. The theme of the aria is taken up again in Act II after Masetto, rather than Zerlina, is beaten. She comforts her man in "Vedrai, carino" by offering him the remedy of Nature ("bel rimedio ... E naturale"), which she carries within herself as a healing balm ("un certo balsam / che porto 
addosso"). As she places his hand on her breast, the "batti" of the earlier aria modulates into "Sentilo battere" of the later aria, her beating heart which he now feels. What she offers-and what he cannot resist-is indeed the remedy of Nature, the purchase on eternity that comes with home, hearth and family and that is a thousand times more powerful than Masetto's masculine strength or the Don's masculine vanity.

Nature as Magna Mater is the biological imperative that drives women, the healing balm that they alone possess and wield before men as the only possible response to mortality. This is why there is no more comical expression than the "war between the sexes." Women have all the power, men none. It is not a war, but a massacre. As Masetto says after the first aria, "See how the little witch gets round me! We men are weak in the head."

JS: One recalls Dr. Johnson's rueful witticism: "Nature has given women so much power over men that the law, in its wisdom, has given them very little." How perfect that the beating heart lies under the swelling bosom, but which is truly the balm men most desire: that generous heart or the appealing breast that o'ertops it? Ideally, both are presented to us but it strikes me that women enjoy power over men not so much because of the balm of their sentimental and emotional generosity, but because that balm offers a physical pleasure that is so intensely gratifying that men lose all judgment when, as the Don says to Leporello, they "scent femininity." I love the way Robert Browning cleverly depicts that sexual power when he has the pathetic Andrea del Sarto exclaim to his wife, "Your soft hand is a woman of itself / And mine the man's bared breast she curls inside." Although she has nothing but her womanliness to recommend her, Lucrezia enjoys all the power over Andrea, who is merely a second-rate artist. He would seem to have her in the palm of his hand, but in fact she dominates him.

I do think women enjoy power over men to the extent that men I) fear mortality, 2) desire progeny, 3) want that "balmy" pleasure that women keep both in their hearts and between their legs, or 4) enjoy the chase. As any or all of I-4 lessen in degree, one becomes less a thrall to Nature and to Women, no? And presumably in later life, these enticements begin to lose their luster. I feel less 
massacred and weak in the head than I did when I was younger. Is that unnatural of me? Or is it simply, finally, growing the hell up and learning that, in some cases, Artifice trumps Nature, the mind governs the body, and-voilà-Ecce Cogito! Or am I just cheering myself up until the next pretty girl flutters into the pub, abolishes my meditations and makes a slavering caveman-or a sonorous Don-out of me?

RB: Do men desire progeny-point two of your four-point erotic program? Perhaps. It is one of the few ways we have of kicking against the pricks of our own mortality. Then again, I'm quite fond of the ending of Last Tango in Paris. Do you remember it? Maria Schneider has just shot Marlon Brando. He stumbles out onto a balcony, looks at Paris one last time and then, before falling dead, takes the chewing gum out of his mouth and sticks it under the railing. That's how I want to go. My only progeny, my purchase on eternity-a drying piece of Wrigley's.

JS: I wonder if a way of kicking against those pricks is not so much progeny (although they often result from sex) but rather sexuality, the perfervid embrace of the Younger Female who makes us temporarily-but intensely_forget our aging bodies and desiccating cynicism. Men often chase younger women because they fear death. Progeny, in every sense, comes afterward. I will wait for a reply before I launch a frontal assault on the socalled Weakness of Men in face of the Eternal-Feminine.

RB: What a dreary thought-Age recovering Youth in the arms of Pubescence. Sex, when it's good, is an end in itself. It has nothing to do with providing therapy for-or indulging the nostalgia of-graying Lotharios.

But I suspect that you will now accuse me of inconsistency. Isn't the "evolutionary imperative" a means rather than an end, you will ask. Yes, of course it is. But here we must distinguish between a species mechanism, designed to ensure the survival of the group, and an individual's desires, which aim simply at achieving pleasure, or more complexly at securing companionship and society alongside pleasure. The sex drive is implanted in us by evolution 
and its logic is reproductive (i.e., it is means-oriented). But the individual experience of love-genuine love-centers exclusively on our desire for the beloved (i.e., it is ends-oriented), indifferent to auxiliary benefits (the "trophy-bride" who flatters masculine vanity).

If I am right and genuine love is always an end-in-itself, then we find ourselves confronted with a Kantian question, which I will now put. To what extent is love disinterested? Isn't it Augustine who said that when we truly love we desire the good not of ourselves but of the beloved?

JS: Killing Death through Sex is a dreary thought only if it cannot be sustained. Otherwise, it's an enlivening practice, as death-defying as other stimulating sports, like alpine skiing and sky-diving. And what is procreation if not killing death through sex? As for "genuine love," I have no idea what that might mean apart from your brisk deconstruction of it very early in this dialogue. If you now want to add a Saint to the mix, so be it. I am happy to think of love as relatively disinterested, but that love certainly has nothing to do with sexual longing or perpetuating the species. Like Milan Kundera, I think sex and love barely overlap. It is appealing - and Christian-to think of love as focused on the beloved, as a kind of idolatry that also has connections to caritas, even to pity. "Love" is a four letter word, obscenelyvague terminologically and dangerously-ambiguous practically. It is a force of Sentiment, where sex is a force of Nature. As for your beloved and, it would seem, ubiquitous Prussian, I must echo a horrid rock star: I Kant get no disinterested satisfaction, even when I am "in love." I am that selfish. And I have plenty of company.

As for the power women enjoy over men, I am not persuaded. Not in the least. Three arguments:

I) Men are physically stronger than women and can sweep them off their feet if they like. That painting with all the Sabine women is not called The Rape of the Roman Soldiers. Even sweet and amiable Chaucer, I recall, was accused of abducting a young woman. Men know they can physically overpower women and often do. Some women even like a dominating masculinity. 
2) Culturally, men are dominant in every way. From Heraclitus to Hawking, from Giotto to Picasso, from Plato to NATO, men have dominated women in Art, Science, Technology, Politics, Philosophy, Music and Literature. True, women have been denied the opportunities to shine in these fields, but that nevertheless reflects the triumph of patriarchy and the fact that Nature designed women for child-bearing, which historically has meant staying home and taking care of kids.

3) Men who know how to seduce women, can and do with great ease. Women are often far needier than men but they play their one trump card (that precious balm) when men show signs of weakness and attraction to them. So I disagree with Dr. Johnson that Nature has given women so much power over men. Women have as much power over men as men give them in moments of weakness, conciliation, pity and ... love.

Love gentles the man, pitches the woman up on the pedestal, generates sonnets and valentines, cools the blood and denatures the huge superiority men enjoy over women. For better or for worse, it has been and continues to be a man's world. I am not crowing about these facts of biology and history. I am merely reporting them. As Virginia Woolf ruefully observed, addressing herself to women: "You have never made a discovery of any sort of importance. You have never shaken an empire or led an army into battle. The plays of Shakespeare were not written by you, and you have never introduced a barbarous race to the blessings of civilization. What is your excuse?"

RB: What I found dreary was not the idea of killing death through sex (la grande mort undone by la petite mort), but of aging men chasing younger women to recover their lost youth. Unlike virtue, depravity is its own reward-an end in itself, not a means to something else.

Yes, sex and love are distinct-just as erōs, agapē and philia are distinct. But the whole point of a novel like Kundera's The Unbearable Lightness of Being is that sometimes they do overlap, which is precisely what happens when Tomas meets Tereza. When these small miracles occur, when the three parts of the brainthe three aspects of the soul-find themselves in improbable and 
breath-taking alignment, then the earth begins to sing and the heavens to glow. My problem with Dante and Petrarch is not that they discover the spiritual side of love but that they deny the physical side. For them it's all St. Paul and no Song of Solomon. Like an arresting painting, a haunting melody, or a memorable line of poetry, "genuine" love-I use the word with no apology-is a work of art, disinterested in the same way that any aesthetic experience is. We want the thing in itself and for itself. There are no ulterior motives.

As to the "war between the sexes": of course men are physically superior to women; of course men have produced more culture and science than the "weaker" sex; and of course men know how to sweet-talk a young lovely into bed. But, at least in the West, custom gives the final say to the woman. Remember the central joke of Don Giovanni. Our hero spends the entire opera chasing after women and never beds a single one. Why? Because they say No. What's a Don to do? Even in Die Entfübrung aus dem Serail (whose setting is, after all, a seraglio!), the Selim declines to take Konstanze by force, even though he has the power to do so. Women decide with whom they shall have sex and on what terms. All the rest is peacock feathers-a lot of strutting and preening before the mirror to distract the puffed-up male from the utter powerlessness of his situation.

JS: Since you have returned to Don Giovanni, I would only suggest that the fact that he enjoys no "conquests" in the opera is to be measured against the hilariously compendious catalogue aria Leporello sings as a tribute to the Don's astonishing success with women. We do not need opera to register the fact that many men have not been at all powerless when it comes to the pursuit of women and sexual consummation. Darwin conjectured, and then proved, that the puffed-up male usually "gets the girl" precisely because he is so handsomely inflated.

When erōs, agapē and philia beautifully fan-tail as a single plumage (quel panache!) that is a display of love, I would agree. It is rare. And often it does not survive that horror of conjugal routine called marriage. It seems to me we are dancing around the eroticized version of the philosophical problem of the One and the Many, a problem Aristophanes sketched so brilliantly during 
his contribution to Symposium. We spend a huge part of our lives rolling around in search of the One that completes us. We may settle for the Many, or revel in it, depending on our luck in discovering that the One we truly fancy makes us whole again. That wholeness is, as you suggest, as integrated, lovely, and complex as a work of art. I do not think this love is an illusion, necessarily. But I do think it is not nearly as reliable, trustworthy, or honorable as one might expect. How many times have people fallen in love with the One only to find, years later, after wormwood, betrayal and recrimination, another One to take her place? At a certain point, that narrative starts to look like the Many, does it not? One begins to wonder if one can trust only what Wallace Stevens called "the interior paramour." Can we, finally, fall in love only with our minds and imaginations? Until we drool into senility, they will not betray us or leave us wanting.

RB: You imagine a cool and cruel Don, effortlessly seducing IO03 Spanish señoritas who collapse into girlish vapors and lose all volition at the mere sight of his massive codpiece. I imagine a harassed and beleaguered Don, gamely trying to live up to his reputation as 1003 publicity-crazed women pursue him from boudoir to boudoir. But however we envision our man, at the end of the night the decision to go to bed or not remains a feminine prerogative. Man proposes and Woman disposes-in both senses of the word. If nothing else, I hope we can agree on this: the notion of women as powerless putty in the hands of an irresistible seducer is a Victorian myth, invented no doubt by the well-bustled wives of the period who were fucking their asses off behind their husbands' backs. As for the "puffed up male," I suspect he's a good deal more successful in the animal kingdom than in the human. The female of our species is not stupid. She understands, along with Sainte-Beuve, that "nothing so resembles a swelling as a hollow."

On the question of love as transforming amalgam of erōs, agape $\bar{e}$ and philia, we agree entirely. And yes, it is rare and, alas, too often fleeting. Does that mean we should become Romantics with a capital $\mathrm{R}$, seeking consolation in our minds and imaginations? I hope not. For that is to go the way of Plato, Dante and 
Petrarch; that is to leave the garden of earthly delights and seek a world beyond; that is to forget that nothing in this benighted existence makes life so completely worth living as the warm and welcoming embrace of a woman.

JS: And her hard, gem-like mind? Let's not forget that! Oh, for a pub-full of Hannah Arendts and Susan Sontags and Daphne du Mauriers. It is our job to help create such winsome bluestockings, is it not? And do we not most successfully cherish what we (partly) create, as Shaw's Pygmalion suggests?

I am left wondering about the Greeks and the observation that they (well, the aristocrats, anyway) glorified the instinct rather than the object of love. Not being an ancient Greek (high- or lowborn), I cannot estimate the justice of that observation. It seems to me the Greeks—-that is, the literary and philosophical Greeks—did a bit of both. They turned Love into a Force of Nature and a Force of Culture, and we have been the beneficiaries of that blending for 2500 years and more. But, as you pointed out, their way of discriminating among erōs, love and friendship was perhaps excelled by an equal talent for blurring them, as when Alcibiades bursts in at the end of Symposium and seizes on the evasive Socrates to both praise and blame him for being so philosophical about love. But even that relatively detached form of love is a thousand times more appealing than the grotesquely-depressive definition of "love" vended to us by Jacques Lacan: "Love is giving something you don't have to someone who doesn't want it." If I believed that, I would curl up and die of despair. If there really is such a thing as love, then it is a lion with satin jaws, a tiger with velvet claws. And we must be forgiven if we endlessly pursue that sweet violence.

RB: As in so many things, the Greeks were right: the instinct of love is eternal, the object ephemeral. Juliet dies, Cleopatra betrays, Ophelia goes mad, but Aphrodite, Dionysus and Pan haunt the dark wood of erōs from the beginning of time to the end. And nothing is likely to vanquish them with the possible exception of Jacques Lacan, who would rather make a diagram of love, complete with mathematical symbols, than make love itself. One begins to fear for the collective psyche of France! 
But however eternal it may be, we cannot embrace pure instinct-except as an abstraction. When the black lightning of love falls, it assumes a specific identity: these lapis-colored eyes, that Gioconda smile, this melody of movement and gesture, that honey of flesh and hair. A simple constellation of the senses and we are driven mad with a longing that rushes through us like a tide of life, which is also a tide of death. For it is here that a strange transformation occurs as erōs touches thanatos. Everything that bound us in time and place, that limited us to the here and now, falls away as we are transported to the rhythmically beating heart of the universe and for one, incandescent moment we cease to be broken and fragmented individuals. We are restored to Earth, to Heaven, to Unity. Until, that is, human voices wake us and we drown.

JS: The Prufrock is in the pudding of love, indeed, but-as you wildly surmise-how quickly (invariably?) does that dessert become desert, the tongue of erōs (as we are creating a tropeical paradise, lost) pushed into the groove-and grave-of thanatos. Wallace Stevens sent us an epigram: "Death is the Mother of Beauty." Everything is more beautiful because we are doomed. And that goes triple for those intoxicating blue eyes that redemptively fall for us, then fall on others before falling into nothingness, the empty sockets of Yorick. But our DNA is in love with Life and perpetuity. The species will continue To Be, even if our individual loves drown, like Ophelia, in Not To Be. 